\title{
The Social Scientist Meets the "Believer": Discussions of God, the Afterlife, and Communism in the Mid-1960s
}

\author{
Miriam Dobson
}

In Elena Chizhova's The Time of Women (2009), a short novel set in the midsixties, three elderly women help their young neighbor raise her daughter. The women secretly christen the girl and teach her about their Orthodox faith. When the girl's mother, Antonina, becomes terminally ill, the following conversation takes place with one of the babushki, Glikeria:

Glikeria tries to comfort [Antonina]. "The Lord himself will sort everything out. In the other world things are quiet and peaceful. In the green pastures

... You see everyone who you have said farewell to. What sins can you have ... Let those tremble, whose path lies to hell."

"I dream of living under communism, Glikeria Yegorovna. Just to have a glimpse of it ... The people who will live to see it are happy."

"Oh!"-she waves her hand.-“When will that happen? They promised it before the war..."

"Before the war they were just guessing . . . But they know now for certain: in 20 years. They say that everything will be different. Machines will do the laundry..."

Raised in the countryside, Antonina believes in various folk practices, but when dying of cancer, a secular, communist vision of the future seems to haunt her, albeit in a confused fashion. The exchange quoted above ends with Antonina calmly contemplating a future communist paradise full of kind and cheerful people like the ones shown on television. "That's right," she nods. "I think that's what paradise is like. Just the way it is on television. I didn't use to believe that. But now I think that this is what it is like. I dream of going there...."1

Chizhova's discussions of God, the afterlife, and communism are, of course, fictional, but such dialogues were indeed taking place in the mid-1960s and they leave their trace in the archival record. In these years, researchers were busy investigating, among other things: believers" "conception of God" in Ivanovo region; their "view of the world" in Tambov; the "emotional influence of religious ritual” in Rivne, Ukraine; and conceptions of social relations

I am grateful to the participants of the 2011 conference at the University of Bremen, "The End of the Soviet Union? Origins and Legacies of 1991," in particular, Serguei Oushakine and Alexandra Oberländer, who acted as commentators on my panel. I would like to thank the other contributors to this special section, who read and commented on the article (in some cases, more than once), and the anonymous reviewers for and editors at Slavic Review who helped me as I developed the original conference paper. Maya Haber, Thomas Leng, and Patrick Vaughan also offered invaluable advice. This research was also presented at the "Science, Religion and Communism in Cold War Europe" conference held in Oxford, May 16-17, 2014, and I am grateful to the contributors for the stimulating discussion.

1. Elena Chizhova, The Time of Women (London, 2012), 236-37. 
in Pskov. ${ }^{2}$ In this article, I offer a close reading of fourteen interview transcripts from a larger number produced as part of the fieldwork conducted in Ivanovo in $1964-65 .^{3}$ The texts provide vivid insight into the religious imagination of Soviet citizens, many of whom were elderly working-class or peasant women, a cohort often awarded little attention in historical studies, although the demographic imbalances generated by the war made them a significant presence in late Soviet society. ${ }^{4}$

The interviews also provide insight into the atheist, or secularizing, goals of the party-state. As Catherine Wanner has recently argued, "Secularization was an integral element to socialist modernity and state building in the USSR.” Although the post-Soviet years saw a religious boom, she argues, we should not see this simply in terms of the regime's failure but rather explore the ways in which the promotion of atheism itself "fueled religious change." This fits with Charles Taylor's invitation to view secularization not simply in terms of what has been lost: "The rise of modernity isn't just a story of loss, of subtraction." Writing on the North Atlantic world, Taylor asserts, "The pattern of modern religious life under 'secularization' is one of destabilization and recomposition, a process which can be repeated many times." In the USSR, secularization was, of course, envisaged as only the first step: religion would first be driven out of public life; later it would disappear altogether. An urge to accelerate toward this future state of universal atheism-an impulse pursued with varying levels of ferocity in different decades - made seculariza-

2. Rossiisskii gosudarstvennyi arkhiv sotsial'no-politicheskoi istorii (RGASPI), fond (f.) 606 (Akademiia nauk pri TsK KPSS), opis' (op.) 4 (Institut nauchnogo ateizma, 196478), delo (d.) 133 (Materialy konkretno-sotsiologicheskogo issledovaniia na temu "predstavleniia sovremennogo veruiushchego o boge," provedennogo Instituta nauchnogo ateizma v gorodakh i selakh Ivanovskoi oblasti, 1964-65); RGASPI, f. 606, op. 4, d. 134 (Materialy konkretno-sotsiologicheskogo issledovaniia na temu "predstavleniia sovremennogo veruiushchego o boge," provedennogo Instituta nauchnogo ateizma v gorodakh i selakh Ivanovskoi oblasti, 1964-66); RGASPI, f. 606, op. 4, d. 148 (Materialy konkretnosotsiologicheskogo issledovaniia "predstavleniia sovremennogo veruiushchego ob otnoshenii mezhdu liud'mi," Pskovskaia oblast', 1964-65); RGASPI, f. 606, op. 4, d. 149 (Materialy konkretno-sotsiologicheskogo issledovaniia "predstavleniia sovremennogo veruiushchego ob otnoshenii mezhdu liud'mi," Pskovskoi oblasti v 1964-65); RGASPI, f. 606, op. 4, d. 156 (Materialy konkretno-sotsiologicheskogo issledovaniia "predstavleniia veruiushchego o kartine mira,” Tambovskaia oblast' 1964-65); and RGASPI, f. 606, op. 4, d. 176 (Materialy konkretno-sotsiologicheskogo issledovaniia "ob emotsial'nom vozdeistvii religioznoi obriadnosti," Rovenskaia oblast', 1964).

3. I studied the results of four research projects archived in RGASPI and took full copies of twenty-four interviews.

4. Stephen Lovell, “Soviet Russia’s Older Generations,” in Stephen Lovell, ed., Generations in Twentieth-Century Europe (Basingstoke, 2007), 205-26. Irina Paperno's study of Evgeniia Kiseleva's autobiographical notebooks is a wonderful exception. Irina Paperno, Stories of the Soviet Experience: Memoirs, Diaries, Dreams (Ithaca, 2009), 118-58. On the demographic imbalance, see Tony Wood, "Russia Vanishes," London Review of Books 34, no. 23 (December 6, 2012): 39-41, at www.lrb.co.uk/v34/n23/tony-wood/russia-vanishes (last accessed September 23, 2014).

5. Catherine Wanner, introduction to Catherine Wanner, ed., State Secularism and Lived Religion in Soviet Russia and Ukraine (Oxford, 2012), 1-2.

6. Charles Taylor, A Secular Age (Cambridge, Mass., 2007), 26.

7. Taylor, A Secular Age, 461. 
tion more militant, violent, and unpredictable than elsewhere and, as a result, the tendency toward "destabilization" and "recomposition" of religious life potentially more acute.

This article explores two key aspects of Soviet secularization. First, I examine believers' heterodox conceptions of heaven and hell. Their departures from and reworkings of church teaching were in part the result of a "domestication" of spiritual life that reduced knowledge of Christian doctrine. ${ }^{8}$ But they testify not only to a failure to reproduce church teaching but also to moments of individual creativity. They demonstrate the interconnectedness of the religious and the secular: the values and aesthetics embodied in the afterlife were rooted in the experience of this life, with the language, aspirations, and frustrations of Soviet existence animating the religious imagination. Furthermore, it suggests that among the poor and socially excluded, visions of the afterlife sometimes articulated a desire for social equality considered missing from Soviet society.

Second, I probe the Soviet state's problematic dependency on atheism. Religion, it has been argued, is essential to the construction of modernity: by dictating the place and nature of acceptable religious behavior, the modern state displays and reaffirms its own power and establishes a dichotomy between the rational and enlightened nature of secular governance and the dangers of untamed, uncontrolled religiosity. ${ }^{9}$ In the Soviet case, the assertion of modernity-packaged as "progress"-was absolutely central to the regime's claim to legitimacy and the binary with religion especially prominent. ${ }^{10}$ But, paradoxically, the Soviet party-state needed believers, even as propagandists labored for their extinction. Take, for example, Nikita Khrushchev's reported boast that one day soon the last priest would be paraded on Soviet television. Even in this much-anticipated moment of religion's destruction, a believer was required in order to publicly display the dark past Soviet power had ousted..$^{11}$ In some cases, believers were presented as irrational and

8. In her work on Georgia and Azerbaijan, Tamara Dragadze uses the term domestication, arguing that because churches and mosques were closed, lay people took over key religious activities and some rituals were performed in the home. She does not see religiosity itself declining. Tamara Dragadze, "The Domestication of Religion under Soviet Communism," in C. M. Hann, ed., Socialism: Ideas, Ideologies, and Local Practice (London, 1993), 148-56.

9. On these dynamics, especially in the colonial and postcolonial context, see Talal Asad, Formations of the Secular: Christianity, Islam, Modernity (Stanford, 2003); Talal Asad, "Reading a Modern Classic: W. C. Smith's 'The Meaning and End of Religion,"” History of Religions 40, no. 3 (Fall 2001): 205-22; and Peter van der Veer and Hartmut Lehmann, introduction to Peter van der Veer and Hartmut Lehmann, eds., Nation and Religion: Perspectives on Europe and Asia (Princeton, 1999), 3-14. For discussions of how these ideas work in the Russian context, see Mark D. Steinberg and Heather J. Coleman, "Introduction: Rethinking Religion in Modern Russian Culture," in Mark D. Steinberg and Heather J. Coleman, eds., Sacred Stories: Religion and Spirituality in Modern Russia (Bloomington, 2007), 1-21; and Wanner, introduction.

10. On why atheism became so central to the revolutionaries' mind-set, see Victoria Frede, Doubt, Atheism, and the Nineteenth-Century Russian Intelligentsia (Madison, 2011).

11. Andrew B. Stone, "Overcoming Peasant Backwardness: The Khrushchev Antireligious Campaign and the Rural Soviet Union,” Russian Review 67, no. 2 (April 2008): 301. 
even violent fanatics, a handy foil to the new Soviet man; in others, they were dupes in need of enlightenment to allow them entry into the communist society under construction. ${ }^{12}$ These rival images of the "believer" jostled, both of them meant to reinforce the binary between modernity and backwardness. In the flesh, however, people who professed a religious faith rarely conformed to either of these prototypes, a fact that made propaganda and ideological work involving their participation potentially hazardous, for they had the potential to unsettle the modernity-backwardness binary.

In his seminal study of late Soviet culture, Alexei Yurchak characterizes ideological representations as "normalized, ubiquitous, and predictable."13 Soviet propagandists at the time themselves would seem to concur: reports about atheist work were often critical of its repetitious and dull nature. ${ }^{14}$ It is intriguing, however, that Yurchak's study does not address atheist work explicitly, despite the huge amount of time and resources that were devoted to it right up until the 1980s. I argue here that atheist projects in fact represent something of an exception to Yurchak's picture, notwithstanding the concerns of contemporaries. The intimacy of the interviews, and the life-anddeath issues they addressed, made them less routinized and perhaps more volatile than suggested by Yurchak's depiction of other ideological work. As Sonja Luehrmann writes, "Even during the decades known as the era of 'stagnation,' Soviet secular culture retained a measure of dynamism."15

In the research projects examined here, atheist work was far from routinized, not least because it required the active participation of believersbelievers who were neither fanatics nor dupes. Organized by social scientists eager to pursue fieldwork now that the straitjacket of Stalinism had been cast off, the interviews brought members of the younger generation-the constructors of tomorrow's communism-into contact with those considered marginal to the Soviet community: religious believers, many of them elderly women. Some interviewees appeared cagey, anxious to give the right answer to their

12. The term foil is taken from Zoe Knox, "Preaching the Kingdom Message: The Jehovah's Witnesses and Soviet Secularization," in Wanner, ed., State Secularism, 244-71. The media's depiction of believers in the 1950s and 1960s is discussed in Miriam Dobson, "Child Sacrifice in the Soviet Press: Sensationalism and the 'Sectarian' in the Post-Stalin Era," Russian Review 73, no. 2 (April 2014), 237-59.

13. Alexei Yurchak, Everything Was Forever, Until It Was No More: The Last Soviet Generation (Princeton, 2006), 14.

14. Writing about the Khrushchev era, Elena Zhidkova notes that the quality of lectures was often considered unsatisfactory and that reports from party raikomy were full of criticism about the standard of atheist propaganda provided. Elena Zhidkova, "Antireligioznaia kampaniia vremen 'ottepeli' v Kuibyshevskoi oblast'," Neprikosnovennyi zapas 59, no. 3 (2008): 108-19, at magazines.russ.ru/nz/2008/3/zh12.html (last accessed October 16, 2014).

15. Sonja Luehrmann, Secularism Soviet Style: Teaching Atheism and Religion in a Volga Republic (Bloomington, 2011), 10. Victoria Smolkin-Rothrock notes that Leonid Brezhnev's attempt at ideological revival at the Twenty-Fourth Party Congress, in March 1971 , led to the CC resolution of July 16, 1971, “on strengthening atheist work among the population" and suggests that atheist work was increasingly complex and contested. Viktoriia Smolkin-Rotrok, "Problema 'obyknovennoi' sovetskoi smerti: Material'noe i dukhovnoe v ateisticheskoi kosmologii," Gosudarstvo, religiia, tserkov' 30, nos. 3-4 (2012): 430-63. 
semiofficial visitors, but others apparently welcomed the opportunity to speak about lives that were hard and lonely, perhaps flattered that their thoughts on God and the afterlife mattered after all.

This kind of fieldwork was, of course, only one side of the Soviet state's approach to religion and its followers. The persecution of those whose faith was less "domesticated," who worshipped publicly and campaigned for greater religious freedom, was unambiguous, and their ordeals were reported widely outside the USSR at the time. ${ }^{16}$ By the final years of the USSR, some religious communities clearly felt their faith was incompatible with Soviet identity. For example, from the 1970s, a Protestant emigration movement mobilized on the basis that it was simply not possible to be Christian in a communist country. ${ }^{17}$ Yet the more equivocal encounters between representatives of the atheist establishment and the believers they interviewed under examination here are also deserving of attention, for they bring to light some of the difficulties the atheist project encountered when it tried to develop techniques other than brute repression.

Ideological work with believers was fundamental to the Soviet project for a number of reasons, I suggest, but one key reason was that it reinforced a dialectical relationship between religion as backwardness and atheism as progress. These attempts to establish "religion" as the antithesis of everything "Soviet," particularly pronounced under Khrushchev, were often rather fragile and contested, as other recent work also testifies. Victoria Smolkin-Rothrock's study of the journal Nauka i religiia (Science and religion), founded in 1959, suggests the atheist establishment was already in a state of crisis by the midsixties, its staff concerned that the combative approach taken so far was failing to meet readers' spiritual needs. The 1964 proposal to ditch the title Nauka i religiia reflected editorial concern that depicting "science" and "religion" as adversaries was no longer the most effective tool for creating atheist dispositions (even if the new titles put forward for consideration still implicitly suggested "the binary opposition of light, science, reason, and life, on the one hand," and "darkness, irrationality, and death," on the other). ${ }^{18}$ Luehrmann's anthropological work in the Volga region reveals that the experience and skills that cultural workers developed in the Soviet era, sometimes directly in the sphere of atheist instruction, have often been transferred to new roles as religious leaders in post-Soviet times; rather than presenting this as a narrative in which "religious and secular form ... simply replace and supersede one another," she speaks of the "constant back-and-forth between the dynamics of secularization and theologization." ${ }^{19}$ Focusing on concrete moments when representatives of the atheist establishment and the believer met face-to-face

16. See, for example, Michael Bourdeaux, Patriarch and Prophets: Persecution of the Russian Orthodox Church Today (London, 1969).

17. See, for example, the petitions written by Pentecostals in the 1970s and 1980s, preserved in the Arkhiv istorii inakomysliia v SSSR (1953-1987) Mezhdunarodnogo obshchestva "Memorial," f. 103, op. 2, dd., 11 and 12, and f. 102, op. 1, d. 43. Several authors announce they would like to go to any non-atheist country.

18. Victoria Smolkin-Rothrock, "The Ticket to the Soviet Soul: Science, Religion, and the Spiritual Crisis of Late Soviet Atheism,” Russian Review 73, no. 2 (April 2014): 171-97.

19. Luehrmann, Secularism Soviet Style, 16, 71-75. 
in the mid-sixties, I examine this kind of "back-and-forth" and reveal just how brittle the religion-atheism binary could prove in practice.

\section{A Decade of Scientific Atheism, 1954-1964}

Before proceeding to the interviews themselves, it is important to establish the context in which they were produced. Antireligious campaigns date back to the earliest years of Soviet power, but the distinctive feature of the atheist measures explored here is the role played by academic institutions. "Scientific atheism" offered an alternative to the more violent techniques often deployed. The growing influence of social scientists who rejected crude socioeconomic models to explain religious belief in favor of more historicized, nuanced accounts brought into existence the individualized and often idiosyncratic encounters studied in the main body of this article.

Antireligious propaganda fell into abeyance during World War II and was revived after Iosif Stalin's death: first with a short crusade in 1954, later a more sustained campaign during the last five years of Khrushchev's rule. In these years, places of worship were shut, ordinary believers faced discrimination, and religious leaders were arrested. ${ }^{20}$ Abusing the criminal justice system for such ideological ends seems to run contrary to the ethos of de-Stalinization, but in other ways the campaigns were in keeping with the spirit of the era, especially the renewed commitment to constructing communism. Moreover, the party's desire to raise the new Soviet person and to eradicate the "vestiges of the past" (perezhitki proshlogo) converged with the revival of the social sciences, a fact that was, in time, to provide a distinctive dimension to antireligious work, especially in comparison with prewar antecedents.

In 1954, the Central Committee decreed that the social sciences should play a role in cultivating atheist worldviews, and over the course of the next two years, new sections devoted to the study of religion and atheism were opened at the history and philosophy institutes at the Academy of Sciences. ${ }^{21}$

20. For recent scholarship on the antireligious campaigns, see Zhidkova, "Antireligioznaia kampaniia"; Irina Paert, "Demystifying the Heavens: Women, Religion and Khrushchev's Anti-religious Campaign, 1954-1964," in Susan E. Reid, Melanie Ilič, and Lynne Attwood, eds., Women in the Khrushchev Era (Basingstoke, 2004), 203-21; Stone, "Overcoming Peasant Backwardness"; Tatiana A. Chumachenko, Church and State in Soviet Russia: Russian Orthodoxy from World War II to the Khrushchev Years, ed. and trans. Edward E. Roslof (Armonk, 2002); M. V. Shkarovskii, Russkaia pravoslavnaia tserkov' $i$ Sovetskoe gosudarstvo v 1943-1964 godakh: Ot "peremiriia" k novoi voine (St. Petersburg, 1995); Michael Froggatt, "Renouncing Dogma, Teaching Utopia: Science in Schools under Khrushchev," in Polly Jones, ed., The Dilemmas of De-Stalinization: Negotiating Cultural and Social Change in the Khrushchev Era (London, 2006), 250-66; and Scott Kenworthy, "The Revival of Monastic Life in the Trinity-Sergius Lavra after World War II," in Wanner, ed., State Secularism, 117-58.

21. On the 1954 decree, see John Anderson, Religion, State and Politics in the Soviet Union and Successor States (Cambridge, Eng., 1994), 6. On the opening of the historians' sector in 1955, see Arkhiv Rossiisskoi akademii nauk (ARAN), f. 457 (Otdelenie istoriia Akademiia nauk SSSR, 1936-1999), op. 1 (1945-1956), d. 390 (Perepiska s Muzeem istorii religii i ateizma o sozdanii sektora religii i ateizma pri institute istoriia, 1955), list (1.) 10. On the development in philosophy, see ARAN, f. 1922 (Institut filosofii Akademii Nauk 
Academics were increasingly able to conduct active research. ${ }^{22}$ This was a radical departure and threw up a host of methodological and theoretical issues. According to the records of discussions held at the Academy of Sciences, not all were happy with the new, "scientific" trajectory antireligious work was taking: some older colleagues expressed nostalgia for their days as bezbozhniki, with one arguing in 1960 that the campaigning style (kampaneiskaia liniia) of the past was needed. ${ }^{23}$ At the same seminar, there were also debates about the extent to which the purely materialist explanations of the Stalin era were adequate for explaining religion's tenacity. One participant, for example, argued that scholars' expectation of a link between "backwardness" and religiosity had not been met. In fact, he said, it was in the advanced (peredovye) collective farms that religious activity was higher: once a kolhkhoznitsa has a washing machine, she has more time to go to church. ${ }^{24}$ L. N. Mitrokhin, a member of the Institute of Philosophy and soon a leading authority on Protestantism in the USSR, countered that there was in fact a link between material conditions and belief but agreed it was not a direct one..$^{25} \mathrm{As}$ the revolution receded, blaming religious belief on socioeconomic differenceunderstood to be a feature of capitalism and not socialism-was increasingly problematic. According to Sergei Alymov's recent work, any claim that such "perezhitki" were the product of deep-rooted social inequalities inherent in

SSSR, 1936-1980), op. 1 (nauchno-organizatsionnye materialy instituta), d. 854 (protokoly zasedanii sektora ateizma, 1956).

22. One of the first field expeditions was to study "sectarians" in Tambov region and was led by A. I. Klibanov (a historian) in 1959 but also involved collaboration with colleagues from the philosophy institute, including L. N. Mitrokhin. See ARAN, f. 1922, op. 1, d. 1002 (Stenogramma soveshchaniia ob organizatsii izucheniia prichin sushchestvovaniia religioznykh verovanii i putiakh ikh preodoleniia, 1960), 11. 47-60; I. A. Malakhova, "Istoricheskaia nauka v SSSR: O rabote nauchnoi ekspeditsii po izucheniiu sovremennogo sektantstva," Voprosy istorii (February 1960): 218-19; and L. M. Mitrokhin, "Izuchenie sektantstva v Tambovskoi oblasti," Voprosy filosofii (January 1960): 143-48. For ethnographers' involvement, see ARAN, f. 457, op. 1, d. 208 (Stenogramma arkheologoetnograficheskoi sessii OIN AN SSSR, posviashchennoi itogam i perspektivam ekspeditsionnykh, 6 aprelia 1959). For a discussion of the connections between history, philosophy, ethnography, and folklore studies (presented in a positive light), see Vladimir N. Basilov, "The Study of Religions in Soviet Ethnography," in Ernest Gellner, ed., Soviet and Western Anthropology (New York, 1980), 231-42.

23. This comment was made at a meeting of scholars held at the Institute of Philosophy's Atheism Section in June 1960 to discuss "The Reasons for Religion's Survival and Methods for Overcoming It," a volume which the team had been charged with writing by the CPSU Central Committee earlier that year. ARAN, f. 1922, op. 1, d. 1002, 1l. 84-89, $115-18$.

24. ARAN, f. 1922, op. 1, d. 1002, 1. 45. A few years later, a Ukrainian study would make a similar argument: A. A. Eryshev gave examples of economically more developed villages that nonetheless had high levels of religious activity and compared them with others where people "lived materially worse" but were for the most part nonbelievers. Eryshev maintained that the relationship between economic factors and religiosity should be understood in more general terms, and he linked the postwar religious revival to the difficult economic circumstances of those years. A. A. Eryshev, "Opyt konkretnosotsiologicheskikh issledovanii religioznosti naseleniia na Ukraine," in A. I. Klibanov, ed., Konkretnye issledovaniia sovremennykh religioznykh verovanii: Metodika (Moscow, 1967), 143.

25. ARAN, f. 1922, op. 1, d. 1002, 1. 55. 
the country's "socialist" economy bordered on the heretical. ${ }^{26}$ One scholar was certainly troubled at finding reference in a colleague's work to "disparities in property" (imushchestvennoe neravenstvo) as the cause of religion's survival. ${ }^{27}$

Despite-or perhaps because of-these difficulties, in January 1964 a Central Committee decree brought together this rather diffuse research under the auspices of a newly formed Institute of Scientific Atheism. ${ }^{28}$ At a major conference held at the institute in December 1964, the rector of the CPSU's Academy of Social Sciences, Iu. P. Franstev, opened proceedings by noting a shift: "social scientists" (obshchestvovedy) were abandoning literary sources and materials, he said, in favor of "concrete sociological research." ${ }^{29}$ By this, Frantsev did not mean simply collecting and analyzing statistical figures. The institute's work certainly did generate "hard" evidence, but in these years scholars-like Frantsev-frequently expressed a preference for qualitative findings. ${ }^{30}$ At the same time, researchers moved away from purely socioeconomic explanations in favor of individualized methodologies that allowed them to explore the personal dimension. L. V. Mandrygin, from the Department of Philosophy at Voronezh Agricultural University, for example, endorsed an intensive, almost personalized, approach: "We must get to know the kind of life a person has led, the fate of the believer and his family, the situation in which he finds himself, particularly the circumstances that have left the most vivid imprint on his consciousness. This is very important because studying an individual is like seeing a drop of water that reflects the concrete social relations the person is experiencing in a given period, and as a result, in that period of society's historical development." ${ }^{31}$ What Mandrygin had in mind with this formulation became clear in the following sections of his address in which he detailed a five-hour conversation with a Baptist, Mariia K., from the Moscow factory Manometr. He presented her religious belief not as the result of her socioeconomic background but as a reflection of traumatic events in the country's history, such as collectivization (K.'s father had been "repressed" and her mother died during the famine), the war, and a period of "postwar difficulties." ${ }^{32}$ With the effects of the Twenty-Second Party Congress not yet eroded, Mandrygin could blame not only the war but also the terror: Stalin's

26. Sergei Alymov, "Poniatie 'perezhitok' i sovetskie sotsial'nye nauki v 1950-1960-e gg.,” Antropologicheskii forum, no. 16 (2012): 261-87.

27. ARAN, f. 1922, op. 1, d. 919 (protokoly zasedanii sektora, 1957).

28. RGASPI, f. 606, op. 4, d. 1 (Proekt postanovleniia TsK KPSS o nauchnoi razrabotke problem ateizma, 1964-1970), 1. 1. See also Victoria Smolkin, “'Sviato mesto pusto ne byvaet': Ateisticheskoe vospitanie v Sovetskom Soiuze, 1964-1968," Neprikosnovennyi zapas 65, no. 3 (2009), at magazines.russ.ru/nz/2009/3/sm5.html (last accessed October 16, 2014).

29. RGASPI, f. 606, op. 4, d. 18 (Stenogramma nauchno-teoreticheskoi konferentsii Instituta nauchnogo ateizma "metodika i rezul'taty konkretnykh issledovanii religioznykh perezhitkov," 22 dekabria 1964), 11. 4-11.

30. Criticism of empirical approaches is particularly strong in L. N. Mitrokhin, "O metodologii issledovanii sovremennoi religioznosti," in Klibanov, ed., Konkretnye issledovaniia sovremennykh religioznykh verovanii, 35-52.

31. RGASPI, f. 606, op. 4, d. 18, 1. 53.

32. Ibid., 1. 54. 
cult generated a kind of blind faith, he argued, and instilled in people a sense of powerlessness over their own fate, which meant that a person stopped being a "creator of history [tvorets istorii] and was instead turned into either a small cog [vintik] or an instrument of God's will."”33

At this landmark 1964 conference, Frantsev also claimed that lengthy interviews not only helped researchers gain knowledge of the religious landscape but also had an effect on it: believers would begin to reflect on the nature of their faith and perhaps start to question their convictions. ${ }^{34}$ As Smolkin-Rothrock argues, those charged with carrying out the fieldwork were expected to both "accurately describe Soviet believers and at the same time transform these believers into atheists." 35 The concerns of the former bezbozhniki who worried that academic research lacked the campaigning spirit of their earlier antireligious campaigns were thus-at least in theory-allayed: the work being carried out by the institute was itself to contribute to the erosion of religious belief and to the creation of a society of atheists.

The social scientists who met at the Institute of Scientific Atheism to discuss their research often referred to their own adventures in the field, but their contact with believers was not always first-hand. They regularly outsourced the interviewing to party propagandists, atheism lecturers, club managers, teachers, and-overwhelmingly-students. ${ }^{36}$ Some were party or Komsomol members, but not all. As representatives of the atheist establishment, they would meet with a believer, sometimes on a number of occasions, and conduct an interview, following a rough template of questions, but they lacked the researchers' training and experience. The recruit setting out on a mission that was both scientific and didactic in purpose would have been aware of certain conventions he should follow, but a good deal of autonomy and improvisation was required, both in the conduct of the interview and in the write-up that followed. The involvement of young people in the process reflects a third purpose to the interviews: the reinforcement of the atheist message among Soviet youth. Smolkin-Rothrock argues that in the 1960s, there was concern about the growth of "indifference"-in the place of convinced atheism-as well as about the survival of religious belief itself. ${ }^{37}$ In addition to helping

33. Ibid., 1. 58. For a discussion of Stalin's use of the term vintik (which he famously adopted in the 1945 Victory Parade), see R. W. Davies, Soviet History in the Gorbachev Revolution (Bloomington, 1989), 80-81. What is particularly striking is the extent to which Mandrygin's comments also made it into print, in L. V. Mandrygin, Vnutrennyi mir veruiushchego i prichiny religioznosti (Moscow, 1965), 20.

34. RGASPI, f. 606, op. 4, d. 18, 1. 4.

35. Smolkin, "Sviato mesto pusto ne byvaet."

36. Explaining the methodology he had used, the lead researcher on a 1962 project explained that he had recruited 25 students enrolled in evening classes in the atheism department at the University of Marxism-Leninism, 116 students from the Institute of Engineering and Construction, 10 scientific workers from the medical institute, 30 agitators from the party raikom, and 5 members of the regional board of the Knowledge (Znanie) Society. M. K. Tepliakov, "Materialy k issledovaniiu religioznosti naseleniia Voronezha $\mathrm{i}$ Voronezhskoi oblasti," in Klibanov, ed., Konkretnye issledovaniia sovremennykh religioznykh verovanii, 144-45. Luehrmann also notes that teachers and academics recruited their students. See Luehrmann, Secularism Soviet Style, 9.

37. Smolkin, “'Sviato mesto pusto ne byvaet.” 
wean believers from their faith, the Institute of Scientific Atheism's work was meant to counter this worrying trend.

The interviews were thus three-fold in purpose: scientific (recording the informant's beliefs); didactic or missionary (transforming the believer into an atheist); and performative (reaffirming the superiority of educated, atheist culture). They show that the mobilizing ethos that had characterized the Soviet regime from its very inception remained alive at the dawn of the Brezhnev era, but the interviews' multiple, at times competing, goals made for uncertain results.

\section{Identifying the Believer: Identity and Narrative}

In the mid-sixties, the development of scientific atheism as a social science, particularly the turn to sociology and psychology, gave ordinary believers new importance: they were not just a hangover from the prerevolutionary past, destined for extinction as a consequence of socioeconomic progress, but individuals whose personal experience and thoughts mattered. Rather than disappearing into the mists of time, he-or, as was commonly assumed, she-was actively sought out, as both the subject of scientific research and a participant in the ritual of the interview, an event that, as we have seen, was intended to have a transformative effect on her. But who was the "believer"?

For Soviet social scientists in the 1960s, as for their contemporary counterparts, the question of how to measure religiosity and identify believers was never straightforward. ${ }^{38}$ Although purely statistical research was sidelined, attempts to quantify the number of believers within Soviet society persisted, though the classifications became more nuanced and gradated. One survey conducted in Voronezh region in 1968, for example, identified six categories, ranging from "committed/active" believer to "committed/active" unbeliever. ${ }^{39}$ Results indicated that approximately half of the population were passive unbelievers, about 12 percent "active" unbelievers, and a similar proportion believers (including both the "active" and "passive"). About three-quarters of the latter were women; half were over sixty. ${ }^{40}$ Perhaps unsurprisingly published texts from the time give figures suggesting somewhat higher levels of committed atheism. ${ }^{41}$

In the Ivanovo study of 1964-65 examined here, the focus was exclusively on believers, most of whom were already the subject of "individual work" by

38. Sergei Filatov and Roman Lunkin, "Statistika religioznoi i konfessional'noi prinadlezhnosti rossiian: Kakim arshinom merit'?,” in S. B. Filatov, ed., Religiia i rossiiskoe mnogoobrazie (St. Petersburg, 2011), 5-30.

39. Using anonymous questionnaires, the researchers had obtained answers from one in every twenty-seven members of the adult population. RGASPI, f. 606, op., 4, d. 131 (Otchet Voronezhskogo opornogo punkta Instituta, 1968), 11. 3-7, 38-40.

40. RGASPI, f. 606, op. 4, d. 131, 11. 3, 6.

41. The published results of an earlier study in Voronezh gave 38 percent as atheists and 24 percent as "nonbelievers who still made some concessions to the religious attitudes of relatives or acquaintances.” Tepliakov, "Materialy k issledovaniiu," 146. A study in Belorussia put the level of atheism as high as 68 percent. E. G. Filimonov, "Problemy konkretno-sotsiologicheskikh issledovanii religioznosti v sovetskoi literatury (1961-66)," in Klibanov, ed., Konkretnye issledovaniia sovremennykh religioznykh verovanii, 229. 
agitators and propagandists. ${ }^{42}$ Of the fourteen interviewees selected for this article because of the fullness of their responses, twelve were women. Of the two men, one was a Baptist (and a prisoner). The other informants were all Orthodox. The majority of the women were pensioners. For the most part, the interviewers identified their subject simply as "the believer"; a few went further, with four of the transcripts noting that the person was "not an activist within the religious community and was not dependent on it materially." ${ }^{\text {"43 }}$ Using the criteria of the Voronezh survey, they would probably be classified as "formal, passive" (formal'nye, passivnye) believers or even "wavering" (kolebliushchiesia); they had probably already proven to be more receptive to "individual work" than those with a strong sense of their own religious identity (who may well have resented such efforts as an unwelcome intrusion).

Beyond this, it was the stories the interviewees presented that provide researchers-both in the 1960s and today-with a sense of who they were. Let us begin with the transcript of the meeting with Anastasia Alekseeva. ${ }^{44} \mathrm{As}$ presented by the interviewer-an issue addressed later-it is a coherent narrative in which she emerges as a thoughtful, critical woman who shared the Soviet regime's skepticism toward the church as an institution but held on to her belief in God. Now a pensioner living in Ivanovo, she had grown up in the countryside and attended a church school; her mother and grandmother made her pray several times a day and her grandfather was a church warden. But hers was not a blind faith and she provides a vivid picture of early twentieth-century anticlerical sentiment. ${ }^{45}$ They hated their village priest, she said, because he was debauched and had broken the seal of confession, spreading rumors about a parishioner who had buried an illegitimate baby. She used to go to pray at the Suzdal' convent with her mother but harbored doubts about the effectiveness of praying to relics (which she was not able to see) and had suspicions about the relationships between the nuns and neighboring monks. In the 1930s, when churches were shut, she began to pray at home and even at the time of the interview only attended services on important holidays. It was better to pray at home, she said, because churches were

42. According to a Soviet publication from 1966, four surveys conducted by the Institute of Scientific Atheism in 1964-65 resulted in 906 interviews with Orthodox believers (veriushchie-priverzhentsy pravoslaviia). In fact, as we shall see, a small number of Christians of other denominations were also included. It was noted that "systematic individual work" with them had already been carried out by agitators and propagandist-atheists. Of the 906 interviews, 139 were conducted in the Tambov and Ivanovo regions. N. P. Andrianov, R. A. Lopatkin, and V. V. Pavliuk, Osobennosti sovremennogo religioznogo soznaniia (Moscow, 1966), 5, 43. 178-79.

43. RGASPI, f. 606, op. 4, d. 133, 11. 122-23; RGASPI, f. 606, op. 4, d. 134, 11. 85, 106,

44. The names of interviewers and informants have been changed throughout.

45. Gregory Freeze distinguishes between anticlerical sentiment ("a kind of diffuse hostility . . . directed mainly at clerical foibles or individual clerics") and anticlericalism (a doctrinal movement in which “the 'ism' has real meaning”); the latter, he suggests, was relatively weak in nineteenth-century Russia. Anticlerical sentiment seems the most appropriate description here. Gregory L. Freeze, "A Case of Stunted Anticlericalism: Clergy and Society in Imperial Russia," European History Quarterly 13, no. 2 (April 1983): 177-200. 
too crowded and she did not enjoy listening to the women's gossip. This narrative of her religious journey contains several ideas that had long been central to Soviet antireligious propaganda: the corrupt nature of the priesthood, the futility of praying to relics, and the "backwardness" of female-dominated church congregations. ${ }^{46}$

But this withdrawal from church life did not neatly equate with a rejection of religious belief. Her isolation from the communal life of the church obliged Alekseeva to reach her own interpretations of the Bible. Although identified by the interviewer as "semiliterate" (malogramotnaia), she had begun reading the Gospels three years earlier and, finding that it said nothing about fasting, decided that this was an invention by the clergy. On the occasions when she did attend church, she liked some sermons but with others could "neither agree with the priest nor with God." She cited an example that she attributed to Elijah: the prophet was, she said, rebuked for punishing a rich man who stole grain from a poor man by scattering the rich man's grain; God told Elijah that if he was to start punishing everyone so severely, he would have to scatter them all across the world..$^{47}$ Alekseeva argued that God's rebuke was an injustice. "The outcome is that no one defends the poor, neither Elijah, whom God bars from punishing the rich, nor God." ${ }^{\prime 3}$ Despite these doubts, she believed God created the natural world, she prayed regularly to the saints, and she lit small candles, regretful that she could not afford bigger ones.

A pensioner of the same generation, Ol'ga Kuznetsova, had attended a church school before the revolution, but in the early years of Soviet power her religious commitment had waned, particularly once she entered the ranks of the Komsomol. In 1938, however, tragedy struck: her husband was arrested, wrongly convicted, and died in prison. Following this bereavement, coupled with the death of her parents in the same year, Kuznetsova lost her "spiritual equilibrium" (to use the terminology applied by her interviewer). "God again firmly entered her consciousness," it was noted. As recounted by her interviewer, at least, Kuznetsova's life story fit neatly with the thesis put forward by the Voronezh researcher, Mandrygin, who made a connection between terror and faith, arguing that believers were often people who had been caught up "in the violent maelstrom of events that are linked with key landmarks in the development of Soviet society," people whose hopes and plans had

46. On these aspects of antireligious propaganda in the 1920s, see Daniel Peris, Storming the Heavens: The Soviet League of the Militant Godless (Ithaca, 1998), 75-86.

47. It is hard to identify the story. It seems most likely that she in fact refers to a story from the life of Saint Spyridon: During a time of famine, greedy grain vendors who had cunningly stocked up were selling their grain at a very high price. A poor man whose family were starving asked one vendor to show mercy, but he refused to give anything away. The poor man went to Spyridon in despair, and the following night torrential rains fell, sweeping the grains away and scattering them widely; the following morning the poor could scoop up what they needed, and the rich man was punished for his lack of mercy. Given the association between Elijah and extreme weather in Slavic culture, a misattribution seems possible. There does not, however, seem to be a sense that God was critical of the rich man's punishment. A. V. Bugaevskii, Sviatitel' Spiridon, episkop Trimifuntskii: Ego zhizn', podvigi i chudotvoreniia, izlozhennye po grecheskim rukopisiam (Moscow, 2005), at spyridon-trimifuntsky.narod.ru/zitie_003.html (last accessed October 1, 2014).

48. RGASPI, f. 606, op. 4, d. 133, 11. 2-3. 
been shattered by "unexpected events" and by "elements of spontaneity" (elementy stikhiinosti). ${ }^{49}$ Kuznetsova's return to her faith was largely an internalized one, and she tried to avoid praying in front of her children. When not too busy with work and raising three children single-handedly, she did like to attend church for religious holidays and enjoyed the "solemn beauty of the service," but she, like Alekseeva, confessed to some doubts: "She doesn't always believe the priests' sermons. She sometimes reads religious books but doesn't always believe what is written. She prays without icons, addressing God 'directly."'

The 1930s affected Anastasia Alekseeva and Ol'ga Kuznetsova in quite different ways, but it was in this decade that both women developed religious practices and beliefs in which the church establishment played a marginal role and their relationship with God and scripture was direct, independent, and to some extent critical. Their stories reflect the domestication that scholars have attributed to the Stalin-era assault on religious institutions. ${ }^{50}$ Speaking in the wake of Khrushchev's antireligious campaigns, and both surely aware of their depositions' eventual audience, the women undoubtedly accentuated their detached attitude toward the Orthodox establishment. Each woman surely thought carefully about how to articulate her life story in a way that projected her identity as a member of the Soviet community. But both apparently found it possible to do so without denying their religious beliefs, either by stressing their anticlericalism or by invoking the terror, a topic that in 1964 had not yet become entirely taboo. As we see in the next section, the beliefs they and others espoused also suggest the boundary between the Christian and the Soviet was a permeable one, despite the best efforts of Soviet propaganda to assert the "otherness" of religious faith.

\section{Heretical Beliefs? The Soviet Afterlife and the Quest for Social Justice}

In his study of religiosity in postwar Ukraine, P. M. Bondarchuk uses a number of the studies resulting from the kind of fieldwork initiated by the Institute of Scientific Atheism. On the basis of these studies, published from the midsixties until the late 1980s, he argues that the period saw a significant shift in belief, with increasing numbers of those self-identifying as believers taking an individualistic approach to religious doctrine, particularly younger cohorts who sought accommodation between their Christian faith and materialist (stykhiino-materialistychni) understandings of the world and who had less experience of church attendance..$^{51}$ Based on the original interview transcripts, the analysis I offer in this article certainly supports Bondarchuk's claim that respondents did not reproduce Christian doctrine uniformly. However, this heterodoxy appears to have been common to all generations, particularly in terms of their vision of the afterlife (a key focus of the Ivanovo interviews).

49. RGASPI, f. 606, op. 4, d. 18, 1. 56.

50. Dragadze, "The Domestication of Religion."

51. P. M. Bondarchuk, Religiinist' naselennia Ukrainy u 40-80-kh rokakh XX st.: Sotsiokul'turni vplyvy, osoblyvosti, tendentsii zmin (Kiev, 2009), 134-47. 
Moreover, rather than affirming the inevitable rise of scientific worldviews, informants' statements suggest a rather more complicated intermeshing of the Orthodox and the Soviet.

Interviewers were given a list of theological questions they should probe: How did the believer imagine God? Did she know the creed? What was her attitude to the Holy Trinity? What were her expectations for life beyond the grave ${ }^{52}$ Some of the questions they were posed evidently perplexed the interviewees. Ekaterina Cherentsova, for example, pictured God in the form of a man but could not clearly imagine the nature of the Trinity and admitted she had not contemplated it much (the interviewer commented knowingly that "she believes blindly in the dogma"). She did, however, speak at some length of the afterlife. When the body decays, she explained, it goes through a forty-day trial before being sent to heaven or hell, depending on God's assessment of the person. ${ }^{53}$ Like Cherentsova, many interviewees spoke of the forty-day trial, a tenet of Orthodox teaching but also a particularly important phase in folk conceptions of death and the afterlife. ${ }^{54}$ Anna Gorbatova, a sixty-three-year-old housewife identified as being of the Orthodox faith but not a religious "activist," believed that the soul was a "person in miniature" located inside the chest, a conception of the soul not uncommon in folk culture. ${ }^{55}$ After death, Gorbatova said, the soul flies away to the sky, but she did not countenance her own resurrection: according to the interviewer's transcription, she "had heard about judgment day from her grandparents, but she is doubtful that this judgment ever took place." ${ }^{56}$ In contrast, Evgeniia Velikanova, a seventy-eight-year-old pensioner from a family of laborers, said she did not believe in eternal life, asserting that the soul simply dissolves; nor did she believe in hell, arguing that God wouldn't have created such a place for his children..$^{57}$ All the women had clearly reflected on what would happen

52. RGASPI, f. 606, op. 4, d. 134, 11. 1-3.

53. Ibid., 1l. 68-69.

54. Steve Smith explains that while the Orthodox Church never embraced the doctrine of purgatory developed by Catholic theologians, it did take up "the idea that the soul is subject to a particular judgment between the third and fortieth days after death and that it then exists in an intermediate state in the abode of the dead (Hades) until the Last Judgment. During this intermediate period the soul receives a foretaste of the blessings or damnation that will be its final fate." Stiv Smit [Steve Smith], "Spasenie dushi v Sovetskoi Rossii," Neprikosnovennyi zapas 64, no. 2 (2009), at magazines.russ.ru/ nz/2009/2/ss16.html (last accessed October 16, 2014). Elizabeth Warner suggests that the forty-day transitional phase is particularly important in folk beliefs. Elizabeth A. Warner, "Russian Peasant Beliefs and Practices concerning Death and the Supernatural Collected in Novosokol'niki Region, Pskov Province, Russia, 1995. Part I: The Restless Dead, Wizards and Spirit Beings," Folklore 111, no. 1 (April 2000): 67-90; Warner, "Russian Peasant Beliefs and Practices concerning Death and the Supernatural Collected in Novosokol'niki Region, Pskov Province, Russia, 1995. Part II: Death in Natural Circumstances," Folklore 111, no. 2 (October 2000): 255-81.

55. According to Steve Smith, the belief that the spirit required a body of some kind in order to be individuated "meant that folk conceptions of the soul frequently construed it as a small child, or a homunculus." Smit, "Spasenie dushi."

56. RGASPI, f. 606, op. 4, d. 134, 11. 178-79.

57. Ibid., 1. 106. 
to them after death, their formulations showing awareness (albeit sometimes confused) of church teaching as well as the imprint of folk concerns. They also highlight the independent nature of each woman's conclusions about the afterlife-a topic on which almost all respondents had something substantive to say.

The women's reflections on what would happen in "that world" were shaped by the language and aesthetics of life in the Soviet Union and by their own experiences. Despite embracing quite traditional notions of the soul's passage into the afterlife, Cherentsova, for example, had rather more innovative ideas about the selection process for heaven. ${ }^{58}$ As reported, she believed that even a person who has committed quite significant sins on earth might be granted a place in heaven if he was "clever," because such people are necessary "for the building of paradise" (dlia stroitel'stva raia). ${ }^{59}$ Echoing a phrase that was ubiquitous in the early 1960s-the building of communism-this formulation suggested she considered a person's ability to contribute to society, and to help achieve progress, of greater value than purely moral qualities. Another interviewee, thirty-five-year-old Zoia Strelkova, a cleaner at the children's library in Ivanovo, apparently "dissatisfied with life because she doesn't have her own corner, her own specialization, personal life, or family," believed in the eternity of the spirit, saying, "I will die, but my soul will live forever. Death is when we die and that's that. But the soul is eternal, and after my death it will suffer torment for forty days, the angels and the antichrist will be close by, the angels noting all the good characteristics, the devil the bad ones, and whichever side weighs more will be where the soul goes, I'm not scared of death." In her mind's eye, she had a clear idea of what heaven would be like. "Heaven," she said, "is a place where there is everything: food, honey, apples, an apartment, the soul can be joyful. Hell-there the soul boils in tar, it is sickening, there is nowhere to go, you must languish forever." ${ }^{60}$ Her image of heaven included the perhaps universal dream of bountiful food but also a reward specific to Soviet life: the much-coveted kvartira-something out of reach for most unmarried cleaning women in the USSR.

The living conditions of Anna Bylkova were perhaps more dire still. An illiterate sixty-five-year-old, she shared a kind of cellar (podval'noe pomeshchenie) in Ivanovo. She was Orthodox but only attended church for religious holidays. The summary of her interview is an unusually short one, but its richness makes it worth citing in full.

The believer thinks that everything was created by God, that we are all in God's hands [khodim pod bogom] and live by his mercy. Has a confused understanding of the soul, but thinks that it (the soul) is located inside a person. Upon death, the soul leaves the body in the form of its owner and stands before God's court. The soul of sinners lives forever in hell; the soul of the innocent in heaven.

58. Ibid., 11. 68-69.

59. Ibid., 1. 69.

60. Ibid., 1. 157. Also cited in Andrianov, Lopatkin, and Pavliuk, Osobennosti sovremennogo religioznogo soznaniia, 41. 
The interviewee fears death, fears illness.

Prays for the dead. Goes to church to pray for forgiveness for the sins of the dead, and her own.

Thinks that at Easter the spirits of the dead sit at the table with her and share the meal, although the souls of the sinful stand at the threshold. On such days there should be no swearing at the table as this scares off the visiting spirits.

Anna Ivanovna thinks that people are guests on earth; their permanent living place [postoiannoe mestozhitel'stvo] is in the world beyond the grave.

The time for Judgment Day will come, the call will sound and all will stand up before the court. Sinners will fall into hell, which she imagines as a huge cauldron: some will be roasted in pans, others will drag rocks, water. She imagines heaven as a large garden with an abundance of flowers-"like a public garden" ["napodobie skvera"].

Thinks that most people have little chance of getting into heaven; basically only those who perished during the Patriotic War will go to heaven, and those who committed suicide stand no chance.

Why she thinks this, she cannot explain.

However, she thinks that those who suffer on earth will find comfort in the afterlife, and the reverse. For herself, she would like to find deliverance from the woman who shares her room [sosedka po komnate]-Liusia. She is not entirely satisfied with life-she has always been a single woman, and does not have her own apartment.

The believer is not active either at work or in the community. In the afterlife she hopes to find consolation, to meet with the deceased who were close to her-her sisters.

Doesn't make preparations for the afterlife, although sometimes visits churches, to pray for her sins. Leads a full-blooded life [zhivet polnokrovnoi zhizn'iu], quarrels with her [female] neighbors, uses bad language, and so on.

Her notion of resurrection is very vague, experiences fear regarding “judgment day," but this doesn't disturb her spiritual equilibrium. ${ }^{61}$

Thus ended the report composed by I. M. Il'ina, who identified herself as a nonparty, thirty-year-old graduate taking a course in the Department of Scientific Atheism at the University of Marxism-Leninism.

In the visions recorded by anthropologists and folklorists, heaven is often imagined as an uncultivated, natural place, often with grassy fields, woods, and huts, much like the rural Russian landscape. ${ }^{62}$ In contrast, for Bylkova-a former peasant now living on the margins of city life-heaven has a distinctly Soviet feel to it: described as a small urban park (napodobie skvera), paradise would resemble a spruced-up Soviet city center. It was a place where the unremitting zhilishchnyi vopros of Soviet life would finally be resolved and a postoiannoe mestozhitel'stvo awarded. Also like Cherentsova, she had unusual, and in a sense Sovietized, criteria for a person to win entry to heaven: self-sacrifice in the Great Fatherland War.

61. RGASPI, f. 606, op. 4, d. 134, 11. 180-81.

62. Faith Wigzell, "Reading the Map of Heaven and Hell in Russian Popular Orthodoxy: Examining the Usefulness of the Concepts of Dvoeverie and Binary Oppositions," Forum for Anthropology and Culture, no. 2 (2005): 347-50. 
Even from the brief summary offered by the interviewer, the reader gains a tangible sense of the rather lonely, thwarted life led by Bylkova: without a proper corner of her own, she resents Liusia, the woman with whom she is forced to cohabit, and longs for her deceased sisters. However, heaven offers not only decent housing - clearly a key concern-but, in Bylkova's view, something more radical. Herself at the bottom of the social hierarchy, she imagines the afterlife as a reversal of fates: "those who suffer on earth will find comfort in the afterlife, and the reverse." There is a critical dimension to her religious disposition here, an implicit recognition of the huge inequalities that structure Soviet society and which she hopes to see overturned-a phenomenon only conceivable in the afterlife. The interviews with Strelkova and Bylkova suggest that some women who lived on the margins of society-pensioners, cleaning women, the single-envisaged heaven as a place where they would eventually be free from the indignities of collective living as they, poor, unmarried women, experienced it. ${ }^{63}$ There are echoes here of Alekseeva's reaction to God's treatment of Elijah, described above, and her strong desire to see the poor defended.

As Faith Wigzell's work demonstrates, the popular tendency to see the other world as an inversion of our own, with the rich punished and the deserving rewarded, is not in itself new. ${ }^{64}$ But in the Soviet context, the possibility of seeing Christianity's message as one of social justice suggests affinities between Christianity and communism, and this was a proximity that atheist scholars strongly rebutted. In fact, the crib sheet provided to interviewers included a question meant to expose this problematic association: "Is the believer inclined to think that the construction of communism is the fulfilment of Christ's teachings?" 65 One elderly woman, Tat'iana Likhacheva, replied as follows: "Yes, of course. God also wants us to live like that and wants people to live quietly, joyfully. And that's why there will be communism-because God wants it." ${ }^{\prime 6}$ Kuznetsova said, "I imagine Jesus Christ as an individual, as a good, kind, wise person who lived for a long time among the people and taught them kindness, justice, wisdom. Christ, it seems to me, was the first communist. ${ }^{97}$ Others compartmentalized the sacred and secular, one respondent answering, "It is people who build communism and God has nothing to do with this [bog tut ne prichem], but God helps good people in their lives and their work." ${ }^{68}$ Another said she believed in communism and she believed in God and that "the country will arrive at communism, and God will still be God, all by himself [strana pridet k kommunizmu, a bog ostanetsa bogom, sam

63. It has been argued that it was easier for a single person to preserve their faith within Soviet society than for those with a family; it was also, perhaps, more necessary. E. V. Beliakova, N. A. Beliakova, and E. B. Emchenko, Zhenshchina v pravoslavii: Tserkovnoe pravo i rossiiskaia praktika (Moscow, 2011), 432.

64. Wigzell, "Reading the Map,” 355. See also Ia. K. Generozov, "Russkie narodnye predstaveleniia o zagrobnoi zhizni na osnovanii zaplachek, prichitanii, dukhovnykh stikhov,” in A. N. Sobolev, ed., Mifologiia slavian (St. Petersburg, 2000), 239.

65. RGASPI, f. 606, op. 4, d. 134, 1. 3.

66. RGASPI, f. 606, op. 4, d. 133, 1. 124.

67. Ibid., 1. 85.

68. RGASPI, f. 606, op. 4, d. 134, 1. 86. 
po sebe]." ${ }^{\circ 9}$ Perhaps these two women realized that-however counterintuitive it may have seemed-laying claim to a resemblance between Christ and Karl Marx was not in fact the desired response. Bylkova, however, was audacious: rather than communism being the embodiment of Christian values, she implies, God's heaven was the only solution to Soviet socialism's inadequacies.

As he wrote up this research, R. A. Lopatkin, at the time a postgraduate student at the CPSU's Academy of Social Sciences, asserted that belief in the afterlife was, as should be expected, on the wane. But he also noted that in some cases, interviewees' material aspirations were feeding into their vision of the afterlife-for example, the hope of obtaining one's own apartment in heaven. Reasserting the didactic purpose of the interviews, he concluded that in discussing these issues, the propagandist had an ideal opportunity to help the believer understand "it is not in heaven but on earth, and only on earth, that fairness [spravdelivost'] can be achieved. ${ }^{70}$ Other scholars explicitly attacked any association between Christianity and social justice. In 1964, the philosopher A. A. Avetis' ian wrote with great derision of what he considered a current fashion in the west for "Christian socialism," in his eyes, simply a cover for the materialistic, individualistic, reactionary mentality of the church. ${ }^{71}$ Five years later, M. M. Sheinman, a historian and member of the Nauka i religiia editorial board, published a critical account of Christian socialism from the apostolic era to the modern day, stressing how this erstwhile religion of the poor had swiftly been conquered by the state and how the disenfranchised who tried to use the "religious form" to protest against social injustice were branded heretics and silenced..$^{72}$ In Nauka i religiia, too, attempts by the Orthodox Church to "modernize" itself were condemned, in particular, the proclaimed similarities between communism and Christianity. ${ }^{73}$ Resenting any endeavor by the church to reinvent itself for the contemporary world, the atheist establishment worked hard to shore up oppositions. Science-faith remained one important axis, despite growing doubts about its effectiveness, but so too was Christianity-socialism: no one should be looking to God and heaven to escape the social inequalities the revolution had meant to end.

\section{Performers, Missionaries, Collaborators, and Writers: The Multiple Vocations of the Interviewer}

In addition to the enlightenment they were meant to offer the believer, the meetings generated by these research projects were to have an edifying effect on the interviewer, who was scientist, educator, and transcriber all rolled into one. In all the interviews we find what Yurchak calls "performative dimen-

69. RGASPI, f. 606, op. 4, d. 133, 1. 106.

70. Andrianov, Lopatkin, and Pavliuk, Osobennosti sovremennogo religioznogo soznaniia, 42.

71. A. A. Avetis'ian, Kritika sovremennoi religioznoi sotsial'noi filosofii: Ocherki po istorii religii i ateizma (Kiev, 1964).

72. M. M. Sheinman, Khristianskii sotsializm: Istoriia i ideologiia (Moscow, 1969).

73. L. Druianov and P. Kurochkin, "Pravoslavie glazami uchenykh," Nauka i religiia, 1966, no. 5: 37. 
sions," which he sees "reproducing" certain social relations. ${ }^{74}$ Given that the interviewer had both the pen and paper (and thus the means to decide what had or had not been said) and the question list (the power to direct conversation), he was clearly in a privileged position, reproducing certain hierarchies: atheism over religion, science over tradition, and, usually, youth over age. In these years, young people were expected to take an active role in various projects aimed at the collective good; many, even with the detachment of postSoviet hindsight, still remember the enthusiasm they felt for the voluntary work carried out as students. ${ }^{75} \mathrm{By}$ taking part in the project, the interviewers communicated their credentials as socially engaged young atheist Soviet citizens. Some appear moved by what they heard, others disappointed that they could not convert their interviewee to atheism. Yet, on occasion, it seems that instead of simply reinforcing an easy correspondence between atheism, science, and progress in opposition to the dark world of superstitious belief, the experience of conducting the interview in fact opened up new horizons.

We begin with a rather unusual interview. Perhaps it was his evident enthusiasm for the project which won V. I. Pronin, a student from the Ivanovo University of Marxism-Leninism, a meeting with a rather exotic kind of believer: a Baptist prisoner. Pronin wrote up his report under the title "SelfAnalysis of a Believer in God." Clearly disappointed that their meeting had not proved more effective, he explained: "Using a method of self-analysis in my conversations with Z[inov'ev], I tried to help him understand his religious views [razobrat'sia v ego religioznykh vozzreniiakh] and to recognize the influence of contemporary conditions on his consciousness. However, he turned

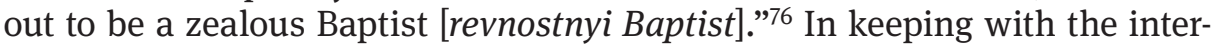
est in psychology demonstrated at the Institute of Scientific Atheism, Pronin spoke of the believer's "consciousness," on which he hoped to act: as a result of the thought processes the interview would encourage, the believer would be transformed into a modern, atheist citizen. Deflated, this student-interviewer noted, however, that the believer resolutely continued to believe in God, "just like before."77

Pronin's report on the interview is a lengthy and detailed account. After setting out the Baptist's history (a young Ukrainian, he had been sentenced for refusing to bear arms or swear the military oath) and his own approach to the interview, Pronin narrates the different exchanges between the two men. One of his opening gambits, for example, was to "dispute the existence of God's paradise" using scientific discoveries to make his case, to which the believer countered that only through God's eyes can one see heavenly paradise. In another, Pronin introduced the USSR's recent triumphs in space travel; Zinov'ev did not deny these successes but attributed them to God's will, argu-

74. Yurchak, Everything Was Forever, 22.

75. See, for example, the oral history interview with Arkadii Darchenko in which he describes how, as students, he, his wife, and friends voluntarily participated in construction projects. Arkadii Olegovich Darchenko, "Our Entire Generation . . . Welcomed Perestroika," in Donald Raleigh, ed., Russia's Sputnik Generation: Soviet Baby Boomers Talk about Their Lives (Bloomington, 2008), 141-42.

76. RGASPI, f. 606, op. 4, d. 133, 1. 65.

77. Ibid., 1. 65. 
ing that, according to the Bible, the laws of nature are revealed to those who fear God, a position then challenged by Pronin, who noted that Soviet cosmonauts, as atheists, are not afraid of God. ${ }^{78}$ The report continues in this vein: the interviewer's own question or claim is followed by the believer's response, the inadequacies of which are made clear to the reader. The encounter is thus presented as a contest between two entrenched positions, one clearly superior. Although disappointed that his mission to save the believer has failed, the student had no difficulty in dealing epistemologically with the situation: in both the irrationality and stubbornness of his answers, the prisoner clearly matched what was to be expected of an active believer. In many respects, this interview is quite different from the others examined here, not only because of the interviewee's denomination, age, and gender, but also because he was serving time as a conscientious objector; he had evidently decided certain civic responsibilities were incompatible with his religious beliefs and was ready to endure prison rather than fulfil them.

Rather shorter transcripts were produced by Sokolov, a fourth-year student medic who conducted interviews with at least two female pensioners from the city of Ivanovo. In writing up his reports, Sokolov chose to present the dialogue in the form of questions and answers, apparently verbatim. From the transcript, it appears that neither of the two exchanges lasted very long, although a couple of notes in parenthesis providing supplementary details suggest other, off-record exchanges, perhaps having taken place in earlier, unrecorded meetings. As presented, his believers appear relatively reticent, offering only laconic answers to his questions. We have already met one of them, Likhacheva, who answered a question about God and communism with the claim that "God also wants us to live like that and wants people to live quietly, joyfully. And that's why there will be communism-because God wants it." ${ }^{\prime 9}$ Curiously, another of Sokolov's interviewees responded with exactly the same answer, word for word.$^{80}$ How to explain the exact replication between two transcripts? Perhaps both women had said something similar, surmising (wrongly) that an equation between God and communism was the required answer. Perhaps Sokolov had typed up his notes in haste, inadvertently copying the wrong section or inventing sections that were missing. We cannot know. Yet, following insights from Yurchak's work, we should not assume that Sokolov was cynically acting out a part when he turned up on his interviewees' doorsteps, even if he did not pay as much attention to his elderly informants' observations as other students did. In Yurchak's terms, he had "reproduced" himself as a "normal Soviet person." 11

Nothing in either of these two sets of interviews suggests that the didactic, or missionary, impulse was successful. Sokolov, perhaps, had no expectation that it would be; Pronin was sorely disappointed with his failure. In both

78. Ibid., 1.66. On the connections between atheist work and space travel, see Victoria Smolkin-Rothrock, "Cosmic Enlightenment: Scientific Atheism and the Soviet Conquest of Space," in James T. Andrews and Asif A. Siddiqi, eds., Into the Cosmos: Space Exploration and Soviet Culture (Pittsburgh, 2011), 159-94.

79. RGASPI, f. 606, op. 4, d. 133, 1. 124.

80. Ibid., 1. 115.

81. Yurchak, Everything Was Forever, 25. 
cases, though, the performative dimension was in play: the unequal relationship between interviewer and interviewee-the educated atheist and the backward believer-was reproduced. In the three interviews explored below, however, the binary of atheist and believer starts to crumble, and unexpected moments of intimacy break into the text.

Let us return to the story of Ol'ga Kuznetsova. Conducted by a second-year student in the Department of Scientific Atheism at the Ivanovo University of Marxism-Leninism, it finishes with a surprising revelation: "I chose my own mother as the object of my chat [Ob"ektom dlia besedy ia izbrala svoiu mat']. I knew that my mum [mama] believes in God but had never spoken with her about religious matters. When I began the discussion about God and her faith, she responded enthusiastically." 82 Speaking of her mama as the object of her research, this student blended impersonal, academic language with more affectionate terms. Choosing her own mother as interview material might initially seem to be evidence of a rather perfunctory approach to the assignment, but given the content of the conversation, it was hardly the "safe" option. In March 1964, with Khrushchev still in power, discussion of the terror and one's own fate was possible but still daring. This is evident from the typed manuscript: in a paragraph on terror, the word unjustly is written by hand, as if something else below had been erased or a tentative blank left in a first draft. Aware that the conversation, although conducted within the family home, was meant for an external audience, the daughter-student had perhaps been wary of how to present her troubled family history. To an extent, the domestic nature of this beseda fits more closely with Chizhova's fictional account, in which discussions of faith, and indeed political persecution, take place only within the context of the family home. Yet in this household, scarred by the terror, religious faith had long been off limits, and it was only as a result of a research project conducted by an external body that it turned into a legitimate topic of family conversation, an opportunity the devout mother seemingly welcomed.

Another interview brought together two men in their 30s, both of whom had completed technical school. Gennadii Shevtsov (the believer) had a technical job in construction; Beliaev (the interviewer) identified himself as being a "nonparty" man who was taking a course in the Department of Scientific Atheism at the Ivanovo University of Marxism-Leninism. ${ }^{83}$ The transcript details the beliefs held by Shevtsov, including the notion that God is everywhere and created the world; that God answers prayers that ask for help and support but not ones that try to inflict misfortune on others; and that there is no afterlife. He said that he did not attend church and did not enter into discussions about his religious beliefs because he realized it was inappropriate for a person of his age and educational level to do so. At the end of the three-page report, after summarizing the man's key religious views, the text ends rather abruptly: "No one in his family knows about his faith." Given that he had become the subject of "individual work," his faith cannot have been entirely secret, but this young man, normally too self-conscious to admit to his beliefs,

82. RGASPI, f. 606, op. 4, d. 133, 11. 85-87.

83. Ibid., 11. 77-79. 
had, it seems, spent several hours sharing his ideas about God and the creation of life, divine punishment and intervention, prayer, and the existence or nonexistence of an afterlife. ${ }^{84}$ The sudden ending to the transcript suggests the interviewer was himself struck by the significance of the revelation.

For both Kuznetsova (the mother) and Shevtsov, the interview provided them with the opportunity to speak about beliefs that normally were offlimits. Rather than convincing them that their views were erroneous and outdated, the experience was, as the transcripts suggest, almost cathartic. Both interviewers also found the process moving. Instead of preserving an entirely neutral position, they commented on passages they found affective. Neither presented their reports as verbatim transcripts but instead directed their imagined reader (the academic researcher) to responses they considered "interesting." 85

Finally, we revisit the very first interview analyzed in this article: the encounter with Anastasia Alekseeva. Here the interviewer took a radically different approach to the task of writing up the report. Instead of presenting the dialogue verbatim (as Sokolov had done) or summarizing the exchanges (the path others selected), the student, Volkov, wrote in the first-person, as if he had become his interviewee: "I imagine God as the human savior"; "I know about there being three Gods [o tom, chto bogov (sic) tri znaiu]"; and so on. ${ }^{86}$ In the text, the interviewer's participation is entirely erased, only the numbers in the margin indicating that Alekseeva was responding to specific questions or prompts and the prose too smooth and fluent to be a verbatim transcript of the actual exchange. Through Volkov's act of ventriloquism, Alekseeva tells a life story that incorporates both values encouraged by the Soviet regime (anticlericalism, defense of the poor, anger about social injustice) and ones that were antithetical to Soviet atheist culture (contemplation of the Bible, belief in God as creator of the world, regular prayer). Between the two authors of the text-Alekseeva and Volkov-an identity was constructed that was neither that of a conservative, or duped, believer nor that of a progressive, atheist Soviet citizen.

The interviews thus had the potential to spark unexpected moments of intimacy between atheist and believer. The reports written by Kuznetsova (the daughter) and Beliaev suggest they responded emotionally to the encounter: a quiet pride that her mother had survived such ordeals, even if it required a private faith; a sense of shock that his informant was speaking of beliefs that mattered deeply but of which his family knew nothing. In both cases, the research project generated conversations that would not otherwise have taken place. In the Kuznetsov household, it produced a dialogue about faith and family suffering which both parties appreciated; for Shevtsov, it allowed a conversation about his beliefs which social pressures normally precluded.

84. Ibid., 1. 79.

85. Ibid., 1l. 77, 85. Others did the same. For example, one interviewer noted that it was "interesting" that his informant (a pensioner from Ivanovo) believed that the devil takes the form of a person and lives among people, getting up to his dirty tricks and making them do bad things. See RGASPI, f. 606, op. 4, d. 134, 1. 68.

86. RGASPI, f. 606, op. 4, d. 133, 11. 1-3. 
In the final case, we have a transcript in which the atheist student became the believer, at least temporarily. Through the act of interviewing and writing up the interview, Volkov produced a text in which he imagined what it would be like to be a believer-and one who cherished many of the ideals and values on which the Soviet project was based. In these three cases, at least, the notion of the believer was surely complicated by these unusual encounters, the binary between Soviet modern man and his backward "other" corroded, not reinforced, by the atheist work taking place.

These interviews, and the idiosyncratic texts they produced for the archive, are in part a reflection of the political and intellectual climate of the 1960s. Excited by the new opportunities available after Stalin's death, some scholars prioritized developing new theoretical and methodological approaches to understanding religiosity and belief, but many also subscribed to the idea that their work was additionally, perhaps primarily, about transforming the believer herself. ${ }^{87}$ Although their findings did not always meet the party's expectations, the researchers' work supported one of the party-state's most persistent goals: nurturing atheist dispositions throughout Soviet society. ${ }^{88}$ In some respects, this was typical of a convergence of interests between certain sectors of the intelligentsia and the party leadership which occurred in the 1960s. ${ }^{89}$

The projects had multiple purposes. Both participants in the interviews were involved in a ritual that enacted the superiority of Soviet values (reason, rationality, and enlightenment), but because the initiative was also about seeking and recording knowledge, the content of the performance was left open-ended. This made the interviews rather different from the "rituals and speech acts" described by Yurchak, which were fixed and normative, even

87. Klibanov's first expedition to Tambov, in 1959, it was later noted, was primarily academic in nature, but it was defended on the grounds that the findings would help local propagandists improve their work. See N. P. Krasnikov, "O nekotorykh voprosakh raboty s veruiushchimi," in N. P. Krasnikov, ed., Voprosy preodoleniia religioznykh perezhitkov $v$ SSSR (Moscow, 1966), 5. Other scholars were keen to stress that their projects involved sustained contact between the person conducting the research and their subject, with one noting that a number of visits took place over a period of one to two months and that many of these relationships continued long after the end of the project. Tepliakov, "Materialy $\mathrm{k}$ issledovaniiu," 145.

88. In a 2010 interview, R. A. Lopatkin noted that their work did not always meet with approval from the ideological department of the party's Central Committee. See "Remir Aleksandrovich Lopatkin: K 80-letiiu so dnia rozhdenia," Gosudarstvo, religiia, tserkov' v Rossii i za rubezhom, 2010, no. 4: 239-47.

89. Simon Huxtable explores this convergence of interests in a chapter of his dissertation on the Institute of Public Opinion based at the editorial offices of Komsomol'skaia Pravda. Party leaders and government figures were initially very interested in the findings of this sociological work. See Simon Huxtable, "A Compass in the Sea of Life: Soviet Journalism, the Public, and the Limits of Reform after Stalin, 1953-1968” (PhD diss., University of London, 2013), chap. 4, “'This Number Says a Lot': The Institute of Public Opinion and the Rebirth of Polling in the Soviet Union (1960-68)." On the potential for common ground between party ideologues and writers in the 1960s, see Polly Jones, "The Fire Burns On? The 'Fiery Revolutionaries' Biographical Series and the Rethinking of Propaganda in the Brezhnev Era," in this issue. 
if they went on to produce "diverse, multiple, and unpredictable meanings in everyday life." ${ }^{00}$ In the examples studied here, the ideological work itself had become creative and unpredictable. As I suggest, we can attribute this in part to the political, cultural, and academic flux of the sixties, but it was also characteristic of the Soviet atheist project more broadly.

In the postrevolutionary period, the closure of places of worship and the dismantling of church hierarchies brought about a partial domestication of religion. Of course, this process was not universal, and church attendance never entirely stamped out, but the restrictions on religious life in midcentury Russia meant that many individuals were left to their own devices as they worked toward their own interpretations of the Bible, elaborating their own beliefs about what would happen after death. According to Wigzell, in these circumstances it was "a natural imaginative response" to envisage the world beyond the grave as more like their own..$^{91}$ As we have seen here, this meant that Soviet values and experiences affected ideas about who could enter heaven and what paradise would look like. Among those who were poor and whose lives were sometimes lonely, these included potentially heretical reflections on the still elusive nature of social justice in "this world." One of the unintended consequences of Soviet antireligious policies, therefore, was to encourage "imaginative responses" rather than a straightforward loss of religious sentiment..$^{92}$

As well as raising questions about the unequal nature of Soviet society, this recomposition of religious belief-to use Taylor's terms-was potentially destabilizing because the containment and conquest of religion was so central to the regime's assertion of legitimacy. But it also helped create a role for social scientists whose job was to both narrate and implement the country's uneven progress toward universal atheism. In the final decades of Soviet power, their involvement offered a new brand of atheist work. It again had unintended consequences. It is sometimes asserted that God became a taboo topic in the Soviet regime, but the besedy described here suggest that antireligious initiatives could encourage, rather than stifle, discussion..$^{93}$ In the case of the Kuznetsov household, the task set by the atheist establishment opened up an unprecedented dialogue between mother and daughter about the role of religious faith in their lives and its relationship to the terror. Elsewhere, it brought strangers together to talk about these intimate matters: a student medic interviews a pensioner; a math teacher visits a kolkhoznik. ${ }^{94}$ Conventions dictated that relations between the two participants were imbalanced-as noted above, the performance was meant to reaffirm the superior-

90. Yurchak, Forever Was Forever, 25.

91. Wigzell, "Reading the Map," 360.

92. This kind of heteroglossia I describe for the 1960s continued into the post-Soviet era. See Jarrett Zigon, “Aleksandra Vladimirovna: Moral Narratives of a Russian Orthodox Woman," in Mark D. Steinberg and Catherine Wanner, eds., Religion, Morality, and Community in Post-Soviet Societies (Bloomington, 2008), 85-113.

93. Vitaly Bezrogov, "Between Stalin and Christ: The Religious Socialisation of Children in Soviet and Post-Soviet Russia," Forum for Anthropology and Culture, no. 5 (2009): 301-38.

94. RGASPI, f. 606, op. 4, d. 134, 1. 106; RGASPI, f. 606, op. 4, d. 156, 11. 62-63. 
ity of Soviet values-but at times a connection between the two partners is palpable in the surviving transcripts.

Revived under Khrushchev, and reconfigured by the growing influence of social scientists in the 1960s, the atheist agenda generated a set of performances and texts that allow the researcher insight into the religious imagination of a social cohort often excluded from historical accounts. Their marginalization does not make the believer the antithesis of the Soviet citizen, however. Indeed, the life stories they told and the beliefs they articulated show the impossibility of establishing a stark binary-even an imagined one-between believers and the rest of the Soviet community, however much such a distinction would have helped prove the rational and progressive nature of socialist modernity. 